\title{
Seed priming with zinc improves field performance of maize hybrids grown on calcareous chernozem
}

\author{
Gordana Tamindžić, ${ }^{1}$ Maja Ignjatov, ${ }^{1}$ Dragana Milošević, ${ }^{1}$ Zorica Nikolić, ${ }^{1}$ \\ Ljiljana Kostić Kravljanac, ${ }^{2}$ Dušica Jovičić, ${ }^{1}$ Željko Dolijanović, ${ }^{3}$ Jasna Savić ${ }^{3}$ \\ ${ }^{1}$ Institute of Field and Vegetable Crops, Novi Sad; ${ }^{2}$ Plant Nutrition Research Group, Institute for \\ Multidisciplinary Research, University of Belgrade, Belgrade; ${ }^{3}$ Faculty of Agriculture, University of \\ Belgrade, Belgrade, Serbia
}

\section{Highlights}

- Seed priming with Zn resulted in an average increase of maize grain yield by about 18\% compared to control, and by about $8.4 \%$ compared to water priming.

- Zn-priming promoted plant growth and increased final plant height of three maize hybrids.

- Overall experiment plant growth parameters were correlated with grain yield components and grain yield.

- Overall effect of seed priming on grain Zn concentration was significant, but it was increased by Zn-priming in two hybrids.

- Using the seeds with elevated Zn content can improve overall field performance of maize grown on calcareous chernozem.

\begin{abstract}
Delivery of micronutrients to plants through seed priming improves seedling vigour and increases crops yields. Two-year filed trial was conducted in Pančevo, Serbia, with aim to study the effect of seed priming with zinc ( $\mathrm{Zn}$ ) on field performance of three maize hybrids on calcareous chernozem deficient in plant available $\mathrm{Zn}$. Seed priming treatments were: control (without priming), water priming and priming with $4 \mathrm{mM}$ zinc sulphate water solution. Seed priming had significant effect on early plant growth, plant height, yield components, grain yield and grain $\mathrm{Zn}$ concentration. Zn-priming promoted plant growth and increased final plant height. Across two growing seasons with contrasting precipitation
\end{abstract}

Correspondence: Jasna Savić, Faculty of Agriculture, University of Belgrade, 11000 Belgrade, Serbia. E-mail: jaca@agrif.bg.ac.rs

Key words: Microelement; grain yield; zinc concentration.

Funding: this research was supported by the Ministry of Education, Science and Technological Development of the Republic of Serbia (Contracts No. 451-03-9/2021-14/200032 and 451-03-68-2020$14 / 200053)$

Received for publication: 20 December 2020.

Revision received: 31 March 2021.

Accepted for publication: 18 april 2021.

(C) Copyright: the Author(s), 2021

Licensee PAGEPress, Italy

Italian Journal of Agronomy 2021; 16:1795

doi:10.4081/ija.2021.1795

This article is distributed under the terms of the Creative Commons Attribution Noncommercial License (by-nc 4.0) which permits any noncommercial use, distribution, and reproduction in any medium, provided the original author(s) and source are credited. and three tested maize hybrids, Zn-priming resulted in an average increase of grain yield by about $18 \%$ compared to control, and by about $8.4 \%$ compared to water priming. A significant relationship between plant growth parameters, grain yield components and grain yield was detected. Grain Zn concentration was increased by Zn-priming in two hybrids in the season with less precipitation and in one hybrid in the second season. The results imply that using the seeds with elevated $\mathrm{Zn}$ content can improve overall field performance of maize grown on calcareous chernozem.

\section{Introduction}

Zinc ( $\mathrm{Zn})$ is an essential microelement for higher plants and plays an important role in plant growth, gene expression, structures of enzymes, photosynthesis, pollen development, sugar transformation, protein synthesis, membrane permeability, signal transduction and auxin metabolism (for review see Hacisalihogly, 2020). Soils with low plant-available $\mathrm{Zn}$ and $\mathrm{Zn}$ deficiency in crops are reported in many countries, and around $50 \%$ of cereal production area worldwide has soils with low plant available $\mathrm{Zn}$ (Cakmak, 2009). Availability of $\mathrm{Zn}$ for plants is affected by high soil pH, high bicarbonates and drought (Alloway, 2008), whilst high application of phosphorus fertilizers lowers grain $\mathrm{Zn}$ concentration in wheat and maize (Nikolic et al., 2016; Zhao et al., 2020). Zn can be applied to crops through soil and foliar fertilizers or by seed treatments. Foliar $\mathrm{Zn}$ application may have limited effectiveness (Fageria et al., 2009), including differential response of cultivars to applied form of $\mathrm{Zn}$ as shown for barley (Moshfeghi et al., 2019), whilst in some soils, $\mathrm{Zn}$ can be fixed and consequently not utilized by the crop (Rengel, 2015).

Using seeds with elevated micronutrient content can improve seedling vigour and increase crops yields (Welch, 1986). Nutrient seed priming is a pre-sowing treatment, efficient and low cost technique used to increase nutrients content in seed. There are advantages to this approach, since each seed is exposed to the nutrient which is available in early growth stages, and it is less costly due to less required amounts. Primed $\mathrm{Zn}$ is translocated 
from seeds to shoots during germination and seedling development as shown in maize (Imran et al., 2015) and rice (Prom-u-thai et al., 2012). Maize seed reserves are exhausted at the 3-4 leaf stage (Cooper and MacDonald, 1970); therefore, seed priming with Zn, in addition to seed hydration provides substantial $\mathrm{Zn}$ reserve that plants can utilize at early growth stage. Moreover, seed priming with $\mathrm{Zn}$ alone or with $\mathrm{Zn}$ and $\mathrm{Mn}$ can also help plants to cope with stressful conditions such as salt stress and low root zone temperature, by promoting early plants growth in comparison to water priming (Imran et al., 2013; Imran et al., 2018). In addition, important role of $\mathrm{Zn}$ fertilization for early plants growth was shown for maize by increased net photosynthetic rate in leaf development stage (Liu et al., 2016), and also alleviated drought stress in wheat plants by $\mathrm{Zn}$-mediated increase in photosynthesis pigment and active oxygen scavenging substances, and reduction in lipid peroxidation (Ma et al., 2017). Zn-priming promotes seed germination and seedling vigour in rice and wheat (Rehman et al., 2015, Harris et al., 2008), also germination and field emergence of maize (Foti et al., 2008). Furthermore, Zn-priming was more efficient than Znfoliar treatment in increase of yield of wheat grown on Zn-deficient calcareous soil (Yilmaz et al., 1997) and equally efficient as $\mathrm{Zn}$ addition to soil in maize (Harris et al., 2007). Esper Neto et al. (2020) recently shown that seed priming with nano-scale $\mathrm{ZnO}$ improves maize seedling growth. Positive effect of $\mathrm{Zn}$-priming on grain yield and grain nutritional quality was also shown in common bean (Tabesh et al., 2020). Hassan et al. (2019) also showed that wheat seed priming with $0.01 \mathrm{M}$ zinc sulphate water solution increased straw and grain $\mathrm{Zn} \mathrm{level,} \mathrm{and} \mathrm{the} \mathrm{same} \mathrm{treatment}$ improved the stand establishment, seedling growth, chlorophyll content, morphological and yield parameters, grain yield and seed Zn concentrations in mungbean (Haider et al., 2020a, 2020b).

Plant species differ in their sensitivity to $\mathrm{Zn}$ deficiency, and maize is more susceptible than other crops such as rye or oats (Broadley et al., 2012; Mattiello et al., 2015), and it is the first crop with reported $\mathrm{Zn}$ deficiency symptoms (Maze, 1914). Maize is the top ranked cereal globally, and it is the main crop in terms of cultivated area in Serbia, providing a substantial amount of food supply of $29 \mathrm{~kg} /$ capita/year (FAOSTAT, 2018; http://www.fao.org/faostat/en/\#data). In Serbia, high $\mathrm{pH}$ and often calcareous soils prevail in the one-third of arable land located in the flatland of the Vojvodina Province (Manojlović and Singh, 2012) where soils with low plant-available $\mathrm{Zn}$ were recorded (Nikolic et al., 2016). Yet, little attention is paid to application of $\mathrm{Zn}$ in maize production, and there is a general lack of research on this topic, including seed priming techniques, and grain micronutrients level such as $\mathrm{Zn}$. Therefore, the aim of this study was to examine the effect of $\mathrm{Zn}$ priming on plants growth, yield, yield components, and grain $\mathrm{Zn}$ and protein concentration of maize hybrids grown on calcareous chernozem.

\section{Materials and methods}

\section{Experimental site}

Two-year field trial was conducted under rainfed conditions at experimental site of Institute Tamiš, Pančevo, Serbia in 2015 and 2016. The annual on-site precipitation sum is around $650 \mathrm{~mm}$ and precipitation distribution differs remarkably over seasons, but in Serbia, maize crop is irrigated mostly in double-cropping system. In the first growing season, summer was very warm and dry, and precipitation sum was much lower than in the second maize growing season, also lower in comparison to mean value for ten-year period (Table 1). The chernozem soil had following properties: $\mathrm{pH}$ 8.1 , organic matter $3.1 \%, \mathrm{CaCO}_{3} 11.1 \%$, total $\mathrm{N} 0.21 \%$, ALextractable $\mathrm{P}_{2} \mathrm{O}_{5}$ and $\mathrm{K}_{2} \mathrm{O}$ were $20.0 \mathrm{mg}$ and $25.8 \mathrm{mg}$ per $100 \mathrm{~g}$ of soil, respectively. Concentrations of DTPA-extractable $\mathrm{Zn}$ in soil were $0.53 \mathrm{mg} \mathrm{kg}^{-1}$ and $0.57 \mathrm{mg} \mathrm{kg}^{-1}$ in the first and the second season, respectively. Mineral fertilizers were applied as NPK and urea, with $\mathrm{N} 170 \mathrm{~kg} \mathrm{ha}^{-1}, \mathrm{P}_{2} \mathrm{O}_{5} 60 \mathrm{~kg} \mathrm{ha}^{-1}$ and $\mathrm{K}_{2} \mathrm{O} 60 \mathrm{~kg} \mathrm{ha}^{-1}$.

\section{Plant material and priming treatments}

Seeds of three maize hybrids of different maturity classes NS 6030 (FAO 600), NS 4023 (FAO 400), and NS 3022 (FAO 360) were provided by the Maize Department of Institute of Field and Vegetable Crops, National Institute of the Republic of Serbia, Novi Sad, Serbia. Seed priming comprised of the following treatments: priming with water, priming with $4 \mathrm{mM}$ zinc sulphate $\left(\mathrm{ZnSO}_{4} \cdot 7 \mathrm{H}_{2} \mathrm{O}\right)$ aqueous solution, and non-primed seeds were control. Seeds of all hybrids were primed as described by Imran et al. (2013). During $24 \mathrm{~h}$ treatments, seeds were soaked in distilled water or zinc sulphate solution and placed in the dark. Afterwards, Zn-primed seeds were rinsed thoroughly with distilled water for one minute to remove the priming solution. All treated seeds were air dried close to original weight. Ninety seeds for each hybrid per plot were subjected to priming treatments. Seed $\mathrm{Zn}$ concentration and content were determined before (control) and after Zn-priming treatment (Table 2).

\section{Experimental design, treatments and sampling}

The experiment was laid out as randomized complete block design with four replications. Nine treatments were factorial combination of seed priming (control, water priming and $\mathrm{Zn}$-priming) and three hybrids and were laid on thirty-six plots. The size of each plot consisted of four $5 \mathrm{~m}$ long rows, with a $75 \times 22 \mathrm{~cm}$ sowing pattern. The sowing was performed in the third decade of April in both growing seasons. To obtain plants dry biomass, five random uniform plants were harvested six weeks after emergence, at phenological stage of nine or ten unfolded leaves (BBCH 19), and shoot biomass was oven dried at $80^{\circ} \mathrm{C}$ at a constant temperature. Plant

Table 1. Growing season weather conditions for 2015 and 2016.

\begin{tabular}{|c|c|c|c|c|c|c|}
\hline \multirow[t]{2}{*}{ Month } & \multicolumn{4}{|c|}{ Main air temperature $\left({ }^{\circ} \mathrm{C}\right)$} & \multicolumn{2}{|c|}{ Precipitation (mm) } \\
\hline & 2015 & 2016 & Ten-year mean (2005-2014) & 2015 & 2016 & Ten-year mean (2005-2014) \\
\hline April & 11.9 & 14.1 & 13.7 & 25.0 & 67.8 & 42.0 \\
\hline May & 18.5 & 16.7 & 18.3 & 88.2 & 93.4 & 87.6 \\
\hline June & 23.3 & 21.6 & 22.2 & 20.1 & 160.6 & 83.9 \\
\hline July & 27.5 & 22.5 & 24.1 & 4.8 & 103.2 & 51.7 \\
\hline August & 25.5 & 20.6 & 23.5 & 69.1 & 14.2 & 53.8 \\
\hline September & 20.9 & 17.8 & 18.6 & 86.4 & 39.8 & 53.2 \\
\hline Mean/Sum & 21.3 & 18.9 & 20.1 & 293.6 & 479.0 & 378.2 \\
\hline
\end{tabular}


height was determined at harvest, using five plants per each plot. Maize was harvested at the fully ripe stage and plants from border rows were harvested separately and were not used for further measurements. Grain yield was calculated at $14 \%$ of moisture content. Number of grains per ear and 1000 grain weight were determined, and samples for determination of grain protein and $\mathrm{Zn}$ concentration were taken.

Analytical methods. Zn concentration was measured in seeds and harvested grains, and protein concentration was measured in grains. To obtain grain $\mathrm{Zn}$ concentration samples were air dried and milled, and $0.5 \mathrm{~g}$ of dry samples were microwave digested with $10 \mathrm{ml}$ of $\mathrm{HNO}_{3}+2 \mathrm{~mL} \mathrm{H}_{2} \mathrm{O}_{2}$ (Milestone ETHOS UP, Milstone Inc., Shelton, USA). Grain Zn concentration was determined by inductively coupled plasma optical emission spectroscopy (Varian Vista-PRO CCD Simultaneous ICP-OES, Varian, Inc.). Protein concentration in grain was determined by nearinfrared spectroscopy (NIR Analizer, INSTALAB 600, Dickey John, USA).

\section{Statistical analyses}

Obtained data were processed by ANOVA. The fixed effects of growing season and hybrid on maize shoot dry weight, final plants height, yield components, grain yield and grain $\mathrm{Zn}$ and protein concentration were analysed. Random effects were trial blocks and seed priming. ANOVA procedure and multiple comparison Tukey's test $(\mathrm{P}<0.05)$ were adopted. Statistical analyses was performed using SPSS 15.0 package (IBM Corporation, Armonk, New York, USA) for Windows Evaluation version.

\section{Results}

Zn-priming remarkably increased $\mathrm{Zn}$ concentration and content within the seeds of all examined hybrids (Table 2). Seed Zn content in $\mathrm{Zn}$-primed seeds was 8 to 10 -fold higher than in control.

Significant three-way interactions between growing season, hybrid and seed priming were detected for grain yield and 1000grain weight (Table 3 ). There was a significant interaction between hybrid and seed priming for shoot dry weight and grain yield across two growing seasons (Table 3); differences between means of three hybrids with three seed priming treatments were significant (Figure 1), also when two-way ANOVA was carried out for individual seasons (results not shown). In hybrid NS 6030 relative shoot weight differences between Zn-priming and control (28\%) was greater than in NS 4023 (21\%) and NS 3022 (8\%) (Figure 1). For grain yield, relative differences between Zn-priming and control was greater in hybrid NS 3022 (21\%) than in NS 6030 (19\%) and NS 4023 (12\%). Significant interactions between growing season and seed priming were detected for shoot dry weight, final plant height, grain yield and grain $\mathrm{Zn}$ concentration. There was a significant interaction between growing season and hybrid for final plant height, grain yield, 1000-grain weight and grain protein concentration. Grain Zn concentration and 1000-grain weight were significantly affected by growing season, hybrid and seed priming. When one-way ANOVA was carried out for individual hybrids and growing seasons, showing the effects of seed priming on examined parameters, it was detected that $\mathrm{Zn}$-priming enhanced early plants growth of all tested hybrids; shoot dry weight measured six weeks
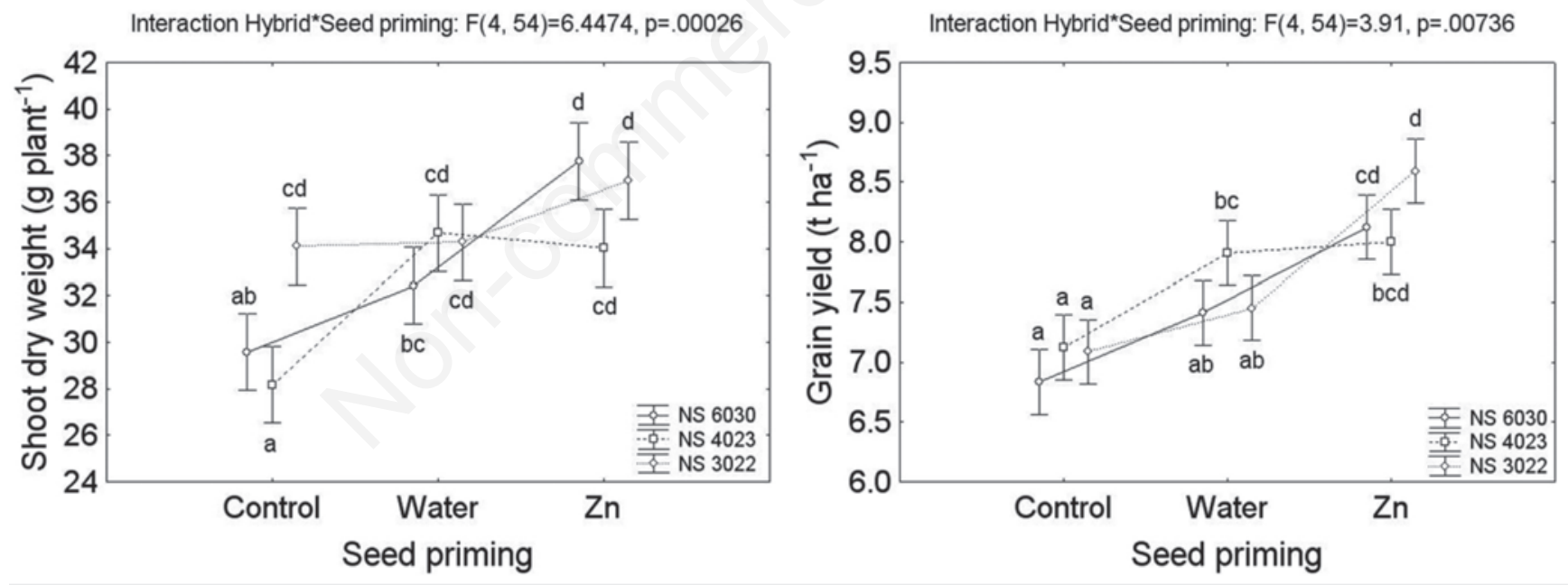

Figure 1. Effect of hybrid and seed priming interaction on shoot dry weight and grain yield of three maize hybrids. Mean values marked with the same letter are not significantly different at $\mathrm{P}<0.05$. Vertical bars denote $95 \%$ confidence intervals.

Table 2. $\mathrm{Zn}$ concentration and content in seeds of maize hybrids before and after $\mathrm{Zn}$-priming.

\begin{tabular}{|c|c|c|c|c|c|c|}
\hline \multirow[t]{2}{*}{ Treatment } & \multicolumn{4}{|c|}{$\begin{array}{l}\text { Hybrids } \\
\text { NS } 4023\end{array}$} & \multicolumn{2}{|c|}{ NS 3022} \\
\hline & $\begin{array}{c}\text { Seed } \mathrm{Zn} \\
\text { concentration } \\
\left(\mu \mathrm{g} \mathrm{g}^{-1}\right)\end{array}$ & $\begin{array}{c}\text { Seed Zn } \\
\text { content } \\
\left(\mu \text { seed }^{-1}\right)\end{array}$ & $\begin{array}{c}\text { Seed } \mathrm{Zn} \\
\text { concentration } \\
\left(\mu \mathrm{g}^{-1}\right)\end{array}$ & $\begin{array}{c}\text { Seed Zn } \\
\text { content } \\
\left(\mu \text { seed }^{-1}\right)\end{array}$ & $\begin{array}{c}\text { Seed } \mathrm{Zn} \\
\text { concentration } \\
\left(\mu \mathrm{g}^{-1}\right)\end{array}$ & $\begin{array}{c}\text { Seed Zn } \\
\text { content } \\
\left(\mu \text { seed }^{-1}\right)\end{array}$ \\
\hline Control & 24 & 10 & 36 & 12 & 36 & 12 \\
\hline Zn-priming & 298 & 116 & 334 & 116 & 258 & 95 \\
\hline
\end{tabular}


after emergence was significantly increased by Zn-priming in comparison to control overall experiment, except in hybrid NS 3022 in the second growing season, and relative increase ranged from 4 to $30 \%$ (Figure 2). In contrast, positive significant effect of water priming on shoot dry weight was recorded only in two hybrids in the first growing season. Final plants height was significantly increased by $\mathrm{Zn}$-priming in comparison to control overall experiment, whilst differences between two priming treatments were significant in the second season (Figure 2). This was supported by significant growing season and seed priming interaction across hybrids (Table 3); relative increase of shoot dry weight and final plants height by water priming in comparison to control in two consecutive seasons was 16.8 and $2.7 \%$, and 3.4 and $2.9 \%$, respectively, whilst increase by $\mathrm{Zn}$-priming was consistent in two seasons (results not displayed).

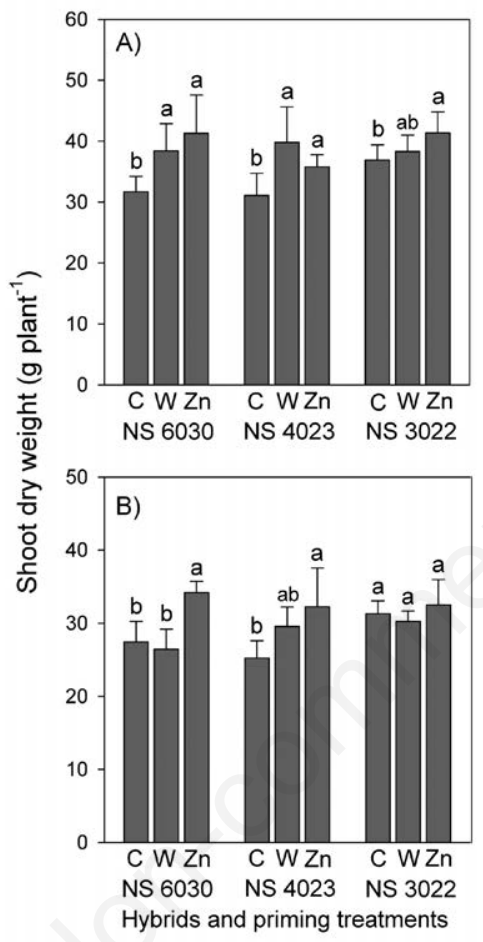

One-way ANOVA revealed that grain yield of tested hybrids was significantly increased by Zn-priming in comparison to control, except in hybrid NS 4023 in the first growing season (Table 4). Yet, increase of yield by $\mathrm{Zn}$-priming differed between hybrids, thus ranged between $8 \%$ and $23.2 \%$, relative to control or water priming. Across two contrasting growing seasons and three tested maize hybrids, Zn-priming resulted in an average increase of grain yield by about $18 \%$ compared to control, and by about $8.4 \%$ compared to water priming (Figure 3).

Similar results were obtained for the effect of $\mathrm{Zn}$-priming on grain number per ear, and for all hybrids in two seasons increase over control ranged from to $5-15 \%$, whilst 1000 -grain weight was less affected by both priming treatments (Table 4). In comparison to control, grain $\mathrm{Zn}$ concentration was increased by $\mathrm{Zn}$-priming in hybrid NS 3022 in both seasons, and in NS 6030 in the first season

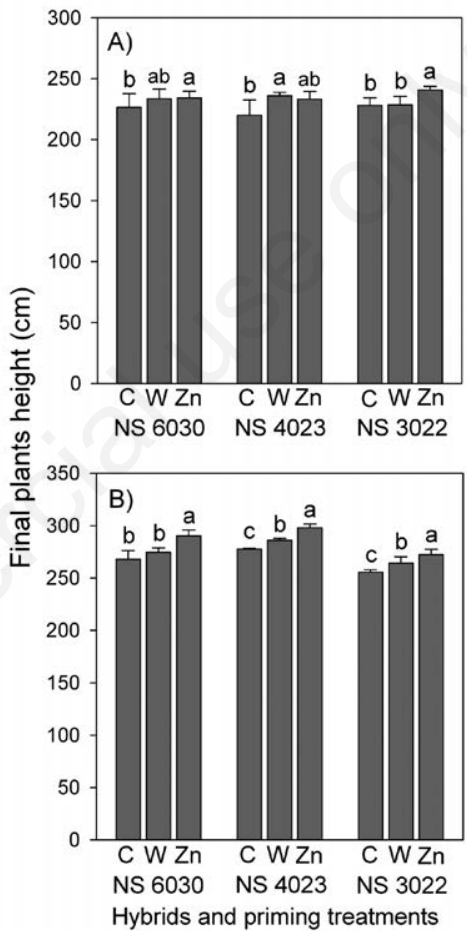

Figure 2. The effect of water priming $(\mathrm{W})$ and $\mathrm{Zn}$-priming $(\mathrm{Zn})$ on shoot dry weight measured six weeks after emergence, and final plant height of three maize hybrids in A) 2015 and B) 2016; C denotes control. Values are means of four replications and the bars represent standard deviation. Mean values for each hybrid and each growing season marked with the same letter horizontally are not significantly different at $\mathbf{P}<0.05$ (after Tukey's test following a 3-way ANOVA).

Table 3. ANOVA results of the effects of growing season, seed priming and hybrid on plants growth, grain yield, yield components, grain $\mathrm{Zn}$ and protein concentration.

\begin{tabular}{lccccccc}
$\begin{array}{l}\text { Source of } \\
\text { variation }\end{array}$ & $\begin{array}{c}\text { Shoot dry } \\
\text { weight }\end{array}$ & $\begin{array}{c}\text { Final plant } \\
\text { height }\end{array}$ & $\begin{array}{c}\text { Grain } \\
\text { yield }\end{array}$ & $\begin{array}{c}\text { Grain } \\
\text { number per ear }\end{array}$ & $\begin{array}{c}\mathbf{1 0 0 0} \text { grain } \\
\text { weight }\end{array}$ & $\begin{array}{c}\text { Grain protein } \\
\text { concentration } \\
\text { concentration }\end{array}$ \\
Growing season (GS) & $<0.001$ & $<0.001$ & $<0.001$ & $<0.001$ & $<0.001$ & 0.14 & $<0.001$ \\
Seed priming (SP) & $<0.001$ & $<0.001$ & $<0.001$ & $<0.001$ & $<0.001$ & 0.50 & 0.0483 \\
\hline Hybrid (H) & $<0.001$ & $<0.001$ & 0.051 & $<0.001$ & $<0.001$ & $<0.001$ & $<0.001$ \\
$\mathrm{GS} \times \mathrm{SP}$ & 0.0019 & 0.0337 & $<0.001$ & 0.07 & $<0.001$ & $<0.001$ & 0.001 \\
\hline $\mathrm{GS} \times \mathrm{H}$ & 0.63 & $<0.001$ & $<0.001$ & 0.07 & 0.42 & 0.16 & 0.09 \\
$\mathrm{SP} \times \mathrm{H}$ & $<0.001$ & 0.50 & $<0.0073$ & 0.54 & 0.0093 & 0.98 & 0.06 \\
\hline $\mathrm{GS} \times \mathrm{SP} \times \mathrm{H}$ & 0.1139 & 0.14 & 0.0016 & 0.63 & & &
\end{tabular}


(Table 5), whilst grain protein concentration ranged from 8 to $9.4 \%$ overall experiment and it was not significantly affected by priming treatments in each tested hybrid (results not shown).

Grain yield was significantly correlated with shoot dry weight, final plant height, number of grain per ear and 1000-grain weight (Table 6). Significant correlation was also detected between plants growth parameters and 1000-grain weight, whilst grain $\mathrm{Zn}$ concentration was correlated with final plant height.

\section{Discussion}

Zn-priming increased the seed $\mathrm{Zn}$ content of all tested hybrids, which was 8 to 10 -fold higher than in control seeds (Table 2). Similar increases were reported in earlier studies after Zn-priming of barley (Ajouri et al., 2004) and maize (Harris et al., 2007; Imran et al., 2013).

Although significant interaction of hybrid and seed priming for shoot dry weight indicated the greatest response of NS 6030 to Znpriming (Figure 1), early plants growth as well as final plants height were significantly promoted in other hybrids in both seasons (Figure 2). Based on growing season by seed priming significant interaction seems that positive effect of water priming on maize growth was more pronounced under conditions with lack of precipitation. Similar results for maize seed Zn-priming and water priming were reported by Harris et al. (2007), whilst water priming did not enhance maize growth in a greenhouse experiments by

Table 4. Effect of priming treatments on grain number per ear, 1000-grain weight and grain yield of maize hybrids in 2015 and 2016.

\begin{tabular}{|c|c|c|c|c|c|c|c|c|c|}
\hline \multirow[t]{2}{*}{$\begin{array}{l}\text { Priming } \\
\text { treatments }\end{array}$} & \multicolumn{3}{|c|}{$\begin{array}{c}\text { Grain number per ear } \\
\text { Hybrids }\end{array}$} & \multicolumn{3}{|c|}{$\begin{array}{c}\text { 1000-grain weight (g) } \\
\text { Hybrids }\end{array}$} & \multicolumn{3}{|c|}{$\begin{array}{c}\text { Grain yield }\left(\mathrm{t} \mathrm{ha}^{-1}\right) \\
\text { Hybrids }\end{array}$} \\
\hline & NS 6030 & NS 4023 & NS 3022 & NS 6030 & NS 4023 & NS 3022 & NS 6030 & NS 4023 & NS 3022 \\
\hline \multicolumn{10}{|c|}{2015} \\
\hline Control & $557^{\mathrm{b}}$ & $616^{\mathrm{a}}$ & $608^{b}$ & $275^{\mathrm{a}}$ & $201^{b}$ & $201^{b}$ & $5.32^{\mathrm{b}}$ & $6.23^{\mathrm{a}}$ & $6.63^{b}$ \\
\hline Water & $546^{b}$ & $597^{a}$ & $605^{\mathrm{b}}$ & $252^{\mathrm{a}}$ & $200^{b}$ & $198^{b}$ & $5.80^{\mathrm{b}}$ & $6.04^{\mathrm{a}}$ & $6.78^{b}$ \\
\hline $\mathrm{Zn}$ & $590^{\mathrm{a}}$ & $657^{\mathrm{a}}$ & $641^{\mathrm{a}}$ & $272^{\mathrm{a}}$ & $218^{a}$ & $233^{\mathrm{a}}$ & $6.55^{\mathrm{a}}$ & $6.14^{\mathrm{a}}$ & $8.17^{\mathrm{a}}$ \\
\hline \multicolumn{10}{|c|}{2016} \\
\hline Control & $651^{b}$ & $686^{\mathrm{b}}$ & $700^{\mathrm{b}}$ & $410^{\mathrm{b}}$ & $371^{b}$ & $352^{\mathrm{a}}$ & $8.36^{\mathrm{c}}$ & $8.02^{b}$ & $7.54^{b}$ \\
\hline Water & $648^{b}$ & $730^{\mathrm{ab}}$ & $794^{\mathrm{a}}$ & $434^{a}$ & $387^{\mathrm{ab}}$ & $324^{\mathrm{b}}$ & $9.02^{\mathrm{b}}$ & $9.78^{a}$ & $8.13^{b}$ \\
\hline Zn & $695^{\mathrm{a}}$ & $754^{\mathrm{a}}$ & $807^{a}$ & $438^{a}$ & $407^{\mathrm{a}}$ & $362^{\mathrm{a}}$ & $9.70^{\mathrm{a}}$ & $9.86^{\mathrm{a}}$ & $9.02^{\mathrm{a}}$ \\
\hline
\end{tabular}

Values are means of four replicates. ${ }^{a, c}$ Mean values marked with the same letter are not significantly different at $\mathrm{P}<0.05$ (after Tukey's test following a one-way ANOVA).

Table 5. Effect of priming treatments on grain $\mathrm{Zn}$ concentration of maize hybrids in 2015 and 2016.

\begin{tabular}{|c|c|c|c|}
\hline $\begin{array}{l}\text { Priming } \\
\text { treatments }\end{array}$ & NS 6030 & $\begin{array}{c}\text { Grain Zn concentration ( } \mathrm{mg} \mathrm{kg}^{-1} \text { ) } \\
\text { Hybrids } \\
\text { NS } 4023 \\
2015\end{array}$ & NS 3022 \\
\hline Control & $21.1^{b}$ & $24.9^{\mathrm{a}}$ & $22.0^{b}$ \\
\hline Water & $22.5^{b}$ & $23.5^{\mathrm{a}}$ & $21.1^{b}$ \\
\hline $\mathrm{Zn}$ & $25.2^{\mathrm{a}}$ & $24.0^{\mathrm{a}}$ & $23.5^{\mathrm{a}}$ \\
\hline \multicolumn{4}{|c|}{2016} \\
\hline Control & $30.4^{\mathrm{a}}$ & $23.4^{\mathrm{a}}$ & $21.9^{\mathrm{b}}$ \\
\hline Water & $33.5^{\mathrm{a}}$ & $25.1^{\mathrm{a}}$ & $23.6^{\mathrm{a}}$ \\
\hline $\mathrm{Zn}$ & $29.9^{\mathrm{a}}$ & $26.5^{\mathrm{a}}$ & $24.3^{\mathrm{a}}$ \\
\hline
\end{tabular}

Values are means of four replicates. ${ }^{a}$, $M e a n$ values marked with the same letter are not significantly different at $\mathrm{P}<0.05$ (after Tukey's test following a one-way ANOVA).

Table 6. Simple correlations between variables evaluated for three maize hybrids grown with seed priming treatments across two growing seasons $(n=36)$.

\begin{tabular}{|c|c|c|c|c|c|c|}
\hline & Grain yield & $\begin{array}{l}\text { Shoot dry } \\
\text { weight }\end{array}$ & $\begin{array}{c}\text { Final plant } \\
\text { height }\end{array}$ & $\begin{array}{l}\text { Number of } \\
\text { grains per ear }\end{array}$ & $\begin{array}{l}\text { 1000-grain } \\
\text { weight }\end{array}$ & $\begin{array}{c}\text { Grain Zn } \\
\text { concentration }\end{array}$ \\
\hline Shoot dry weight & $0.644 * * *$ & & & & & \\
\hline Final plant height & $0.698^{* * *}$ & $0.385^{*}$ & & & & \\
\hline Number of grains per ear & $0.523^{* * *}$ & $0.378^{*}$ & ns & & & \\
\hline 1000-grain weight & $0.706^{* * *}$ & $0.478^{* * *}$ & $0.473^{* * *}$ & $0.867^{* * *}$ & & \\
\hline Grain Zn concentration & ns & ns & $0.430^{* * *}$ & $-0.374^{*}$ & ns & \\
\hline Grain protein concentration & ns & ns & ns & ns & ns & ns \\
\hline
\end{tabular}

*Significant at $\mathrm{P}<0.05$ level; ***significant at $\mathrm{P}<0.001$ level; ns, not significant. 
Subedi and Ma (2005). In contrast, water and both zinc sulphate and nano-Zn-priming did not increase plant height and total dry biomass of forage maize grown on soil with high plant available $\mathrm{Zn}$ (Sharifi et al., 2016). Therefore, additional effect of $\mathrm{Zn}$ on plants growth in present study, can also be associated with concentration of plant-available $\mathrm{Zn}$ in experimental soil that was very close to widely accepted critical deficiency limits of $0.5 \mathrm{mg} \mathrm{kg}-1$ (Cakmak et al., 1999).

Present field study clearly demonstrated that Zn-priming significantly increased grain yield in all tested hybrids (Table 4), resulting in relative increase of $18 \%$ over control across hybrids and two contrasting seasons (Figure 3). Differential response of hybrids to priming treatments and the greatest yield increase by Zn-priming in NS 3022 across two seasons (Figure 1) might be associated with hybrids maturity class and their response to drought stress, and requires further research. Furthermore, positive significant effect of Zn-priming was more pronounced than the effect of water priming on plants growth and yield components (Figure 2, Table 4) which were positively correlated with grain yield (Table 6). Prevailing positive effect of Zn-priming over water priming is consistent with findings by Harris et al. (2007). In addition, water priming has not been efficient for an increase of maize grain yield in temperate-humid conditions (Subedi and Ma, 2005). In study by Mohsin et al. (2014), grain yield was also positively associated with plant height, 1000-grain weight and ear growth parameters of maize under various $\mathrm{Zn}$ applications, including $\mathrm{Zn}$ priming.

Grain $\mathrm{Zn}$ level of all tested hybrids over treatments ranged from 21.1 to $33.5 \mathrm{mg} \mathrm{kg}^{-1}$ (Table 5). This is consistent with study by Brkić et al. (2004) who evaluated large number of maize genotypes in similar agro-ecology. Although priming treatments significantly affected grain $\mathrm{Zn}$ concentration overall experiment, significant increase by $\mathrm{Zn}$-priming in both seasons was recorded in two hybrids, whilst grain protein concentration remained unaffected, and there was no correlation between these grain quality parameters (Table 5). On the other hand, Mohsin et al. (2014) reported significant increase of grain $\mathrm{Zn}$ concentration simultaneously with decrease of protein concentration in two maize hybrids by seed priming with $1 \%$ or $2 \% \mathrm{Zn}$ water solution. Harris et al. (2007) also

Priming effect: $F(2,54)=61.57, p=0.00000$

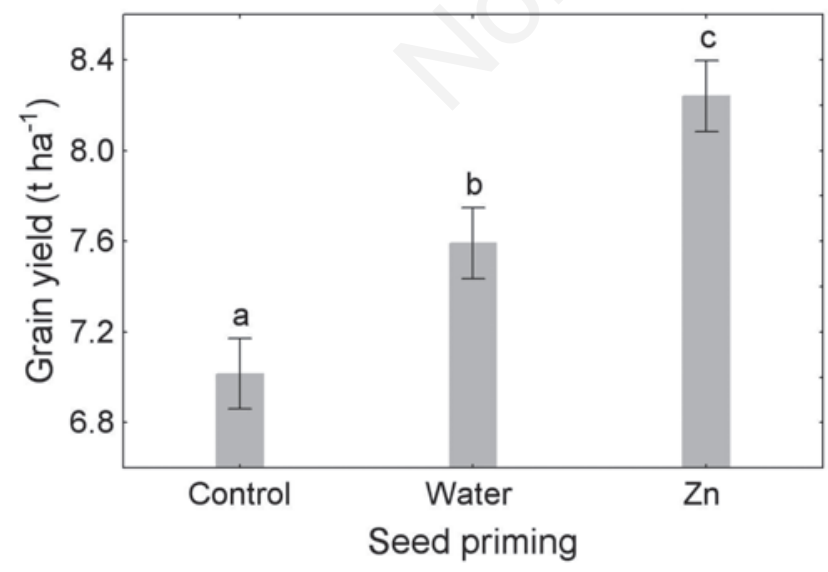

Figure 3. Effect of seed priming treatments on grain yield across two growing seasons and three maize hybrids. Mean values marked with the same letter are not significantly different at $\mathbf{P}<0.05$ (after Tukey's test following a 3-way ANOVA). Vertical bars denote $95 \%$ confidence intervals. obtained remarkable increase of maize grain $\mathrm{Zn}$ level by water and $\mathrm{Zn}$ priming, along with very low grain yields. In our study, increase of grain $\mathrm{Zn}$ level by $\mathrm{Zn}$-priming can be attributed to enhanced plant growth, thus increased nutrients uptake, including $\mathrm{Zn}$. Grain yield is seriously considered in breeding programs for improvement of $\mathrm{Zn}$ level in cereals (Garcia-Oliveira et al., 2018; Mageto et al., 2020). Absence of negative correlation between grain yield and grain $\mathrm{Zn}$ level in present study indicates that grain $\mathrm{Zn}$ level can be maintained with increase of grain yield in modern maize hybrids. Recent studies also confirm that grain $\mathrm{Zn}$ level is not inversely related to wheat grain yield (Chen et al., 2017; Khokhar et al., 2018).

\section{Conclusions}

In summary, the study has demonstrated that Zn-priming increased grain yield of tested maize hybrids grown on calcareous Chernozem potentially deficient in plant available $\mathrm{Zn}$, during two growing seasons with contrasting precipitation regime. Water priming had beneficial effect on grain yield in the season with favourable weather conditions. It appears that $\mathrm{Zn}$-priming promoted plants growth, which led to increase of grain yield components, and in some cases of grain $\mathrm{Zn}$ concentration. Therefore, $\mathrm{Zn}$ delivery to crops through seeds can be used as effective technique to improve grain yield of maize on soils with limited $\mathrm{Zn}$ available to plants.

\section{References}

Ajouri A, Asgedom H, Becker M, 2004. Seed priming enhances germination and seedling growth of barley under conditions of $\mathrm{P}$ and Zn deficiency. J. Plant. Nutr. Soil Sci. 167:630-6.

Alloway BJ, 2008. Zinc in soils and crop nutrition. 2nd edition. IZA and IFA, Brussels, Belgium and Paris, France.

Brkić D, Šimić Z, Zdunić A, Jambrović T, Ledenčan V, Kovačević V, Kadar I, 2004. Genotypic variability of micronutrient element concentrations in maize kernels. Cereal Res. Commun. 32:107-12.

Broadley M, Brown PI, Rengel Z, Zhao F, 2012. Function of nutrients: micronutrients. In Marschner, ed. Marschner's mineral nutrition of higher plants. Academic Press, London, UK, pp. 191-248.

Cakmak I, 2009. Enrichment of fertilizers with zinc: an excellent investment for humanity and crop production in India. J. Trace Elem. Med. Bio. 23:281-9.

Cakmak I, Kalayci M, Ekiz H, Braun HJ, Yilmaz A, 1999. Zinc deficiency as an actual problem in plant and human nutrition in Turkey: a NATO-Science for Stability Project. Field Crop. Res. 60:175-88.

Chen XP, Zhang YQ, Tong YP, Xue YF, Liu DY, Zhang W, Deng Y, Meng QF, Yue SC, Yan P, Cui ZL, Shi XJ, Guo SW, Sun YX, Ye YL, Wang ZH, Jia LL, Ma WQ, He MR, Zhang XY, Kou CL, Li YT, Tan DS, Cakmak I, Zhang FS, Zou CQ, 2017. Harvesting more grain zinc of wheat for human health. Sci. Rep. 7:7016.

Cooper CS, MacDonald PW, 1970. Energetics of early seedling growth in corn (Zea mays L.). Crop Sci. 10:136-8.

Esper Neto M, Britt DW, Lara LM, Cartwright A, dos Santos RF, Inoue TT, Batista MA, 2020. Initial development of corn 
seedlings after seed priming with nanoscale synthetic zinc oxide. Agronomy-Basel. 10:307.

Fageria NK, Filho MPB, Moreira A, Guimarães CM, 2009. Foliar fertilization of crop plants. J. Plant Nutr. 32:1044-64.

Foti R, Abureni K, Tigere A, Gotosa J, Gere J, 2008. The eficacy of different seed priming osmotica on the establishment of maize (Zea mays L.) caryopses. J. Arid Environ. 72:1127- 30.

Garcia-Oliveira AL, Chander S, Ortiz R, Menkir A, Gedil M, 2018. Genetic basis and breeding perspectives of grain iron and zinc enrichment in cereals. Front. Plant Sci. 9:937.

Hacisalihogly G, 2020. Zinc (Zn): The last nutrient in the alphabet and shedding light on $\mathrm{Zn}$ efficiency for the future of crop production under suboptimal Zn. Plants 9:1471.

Haider MU, Hussain M, Farooq M, Nawaz A, 2020a. Zinc nutrition for improving the productivity and grain biofortification of mungbean. J. Soil Sci. Plant Nutr. 20:1321-35.

Haider MU, Hussain M, Farooq M, Nawaz A, 2020b. Optimizing zinc seed priming for improving the growth, yield and grain biofortification of mungbean (Vigna radiata L.). J. Plant Nutr. 43:1438-46.

Harris D, Rashid A, Miraj G, Arif M, Yunas M, 2008. 'On-farm' seed priming with zinc in chickpea and wheat in Pakistan. Plant Soil. 306:3-10.

Harris D, Rashid A, Miraj G, Arif M, Shah H, 2007. 'On-farm' seed priming with zinc sulphate solution - A cost-effective way to increase the maize yields of resource-poor farmers. Field Crop. Res. 102:119-27.

Hassan N, Irshad S, Saddiq M, Bashid S, 2019. Potential of zinc seed treatment in improving stand establishment, phenology, yield and grain biofortification of wheat. J. Plant Nutr. 42:1676-92.

Imran M, Boelt B, Mühling K-H, 2018. Zinc seed priming improves salt resistance in maize. J. Agron. Crop Sci. 204:390-9.

Imran M, Mahmood A, Römheld V, Neumann G, 2013. Nutrient seed priming improves seedling development of maize exposed to low root zone temperatures during early growth. Eur. J. Agron. 49:141-8.

Imran M, Maria K, Römheld V, Neumann G, 2015. Impact of nutrient seed priming on germination, seedling development, nutritional status and grain yield of maize. J. Plant Nutr. 38:1803-21.

Khokhar JS, Sareen S, Tyagi BS, Singh G, Wilson L, King I P, Young SD, Broadley MR, 2018. Variation in grain Zn concentration, and the grain ionome, in field-grown Indian wheat. PLoS One. 13:e0192026.

Liu H, Gan W, Rengel Z, Zhao P, 2016. Effects of zinc fertilizer rate and application method on photosynthetic characteristics and grain yield of summer maize. J. Soil Sci. Plant Nutr. 16:550-62.

Ma D, Sun D, Wang C, Ding H, Qin H, Hou J, Huang X, Xie Y, Guo T, 2017. Physiological responses and yield of wheat plants in zinc-mediated alleviation of drought stress. Front. Plant Sci. $8: 860$.
Mageto EK, Lee M, Dhliwayo T, Palacios-Rojas N, San Vicente F, Burgueño J, Hallauer AR, 2020. An evaluation of kernel zinc in hybrids of elite quality protein maize (QPM) and non-QPM inbred lines adapted to the tropics based on a mating design. Agronomy-Basel. 10:695.

Manojlović M, Singh BR, 2012. Trace elements in soils and food chains of the Balkan region. Acta Agr. Scand. Section B-S P. 62:673-95.

Mattiello EM, Ruiz HA, Neves JCL, Ventrella MC, Araújo WL, 2015. Zinc deficiency affects physiological and anatomical characteristics in maize leaves. J. Plant Physiol. 183:138-43.

Maze P, 1914. Influences respective des elements de la solution minérale sur le development du mais. Ann. Inst. Pasteur. 28:21-68.

Mohsin AU, Ahmad AU H, Farooq M, Ullah S, 2014. Influence of zinc application through seed treatment and foliar spray on growth, productivity and grain quality of hybrid maize. J. Anim. Plant Sci. 24:1494-503.

Moshfeghi N, Heidari M, Asghari HR, Baradaran Firoz Abadi M, Abbott LK, Chen Y, 2019. Effect of zinc foliar application and mycorrhizal inoculation on morpho-physiological traits and yield parameters of two barley cultivars. Ital. J. Agron.14:67-77.

Nikolic M, Nikolic N, Kostic Lj, Pavlovic J, Bosnic P, Stevic N, Savic J, Hristov N, 2016. The assessment of soil availability and wheat grain status of zinc and iron in Serbia: implications for human nutrition. Sci. Tot. Environ. 553:141-8.

Prom-u-thai C, Rerkasem B, Yazici A, Cakmak I, 2012. Zinc priming promotes seed germination and seedling vigor of rice. J. Plant Nutri. Soil Sci. 175:482-8.

Rehman A, Farooq A, Ahmad R, Basra SMA, 2015. Seed priming with zinc improves the germination and early seedling growth of wheat. Seed Sci. Technol. 43:262-8.

Rengel Z, 2015. Availability of Mn, Zn and Fe in the rhizosphere. J. Soil Sci. Plant Nutr. 15:397-409.

Sharifi R, Mohammadi K, Rokhzadi A, 2016. Effect of seed priming and foliar application with micronutrients on quality of forage corn (Zea mays). Environ. Exp. Biol. 14:151-6.

Subedi DM, Ma BL, 2005. Seed priming does not improve corn yield in a humid temperate environment. Agr. J. 97:211-8.

Tabesh M, Kiani S, Khoshgoftarmanesh AH, 2020. The effectiveness of seed priming and foliar application of zinc- amino acid chelates in comparison with zinc sulfate on yield and grain nutritional quality of common bean. J. Plant Nutr. 43:2106-16.

Welch RM, 1986. Effects of nutrient deficiencies on seed production and quality. Adv. Plant Nutr. 2:205-47.

Yilmaz A, Ekiz H, Torun B, Gultekin I, Karanlik S, Bagci SA, Cakmak I, 1997. Effect of different zinc application methods on grain yield and zinc concentration in wheat cultivars grown on zinc-deficient calcareous soils. J. Plant Nutr. 20:461-71.

Zhao QY, Xu SJ, Zhang WS, Zhang Z, Yao Z, Chen XP, Zou CQ, 2020. Identifying key drivers for geospatial variation of grain micronutrient concentrations in major maize production regions of China. Environ. Pollut. 266:115114. 